\title{
Helminths parasites of stray dogs (Canis lupus familiaris) from Cuiabá, Midwestern of Brazil
}

\section{Helmintofauna de cães errantes (Canis lupus familiaris) de Cuiabá, Centro-Oeste do Brasil}

\author{
Dirceu Guilherme de Souza Ramos ${ }^{1 *}$; Bruna Karina Alexandria Zocco²; \\ Mariana de Medeiros Torres ${ }^{1}$; Ísis Assis Braga ${ }^{1}$; Richard de Campos Pacheco ${ }^{3}$; \\ Afonso Lodovico Sinkoc ${ }^{3}$
}

\begin{abstract}
Helminths cause respiratory and gastrointestinal infections in animals, especially in neonates and young animals. Some species of helminth parasites of domestic animals have zoonotic potential, becoming a public health problem, especially when combined with lack of information about the population of these zoonosis and lack of control over of their hosts. This study aimed to identify and quantify the species of helminths from dogs that are not domiciled in the region of Cuiabá, in the Midwest region of Brazil. A total of 100 animals, from the Center for Zoonosis Control of Cuiabá were euthanized and necropsied for helminth searching. Overall 8,217 helminths were found in 85 animals identified in six species: Ancylostoma caninum, Ancylostoma braziliense, Trichuris vulpis, Toxocara canis, Dirofilaria immitis and Dipylidium caninum. It was evidenced the wide distribution of helminths pathogenic to domestic dogs and especially with zoonotic potential as A. caninum, T. canis, D. caninum and D. immitis. The presence of $D$. immitis is an important finding, since it is a potentially zoonotic agent, however, this finding is considered sporadic.
\end{abstract}

Key words: Parasitism, Ancylostoma, Larva migrans, dirofilariasis, zoonosis

\section{Resumo}

Helmintos causam infecções respiratórias e gastrointestinais em animais, especialmente em neonatos e animais jovens. Algumas espécies de helmintos de animais domésticos possuem potencial zoonótico, se tornando um problema de saúde pública, especialmente quando adicionados a falta de informação da população sobre estas zoonoses e a falta de controle da população de hospedeiros. Este estudo objetivou identificar e quantificar as espécies de helmintos de cães não domiciliados na região de Cuiabá, Centro-Oeste do Brasil. Um total de 100 animais do Centro de Controle de Zoonoses de Cuiabá foram eutanasiados e necropsiados para a procura de helmintos. Ao todo 8.217 helmintos foram encontrados em 85 animais e identificados em seis espécies: Ancylostoma caninum, Ancylostoma braziliense, Trichuris vulpis, Toxocara canis, Dirofilaria immitis e Dipylidium caninum. Ficou evidente a alta distribuição de helmintos patogênicos para cães e especialmente com potencial zoonótico como A. caninum, T. canis, $D$. caninum e D. immitis. A presença de D. immitis é um achado importante, considerando o potencial zoonótico do agente, entretanto, o achado é considerado esporádico.

Palavras-chave: Parasitismo, Ancylostoma, Larva migrans, dirofilariose, zoonose

\footnotetext{
${ }^{1}$ Discentes de Doutorado, Universidade Federal de Mato Grosso, UFMT, Cuiabá, MT, Brasil. E-mail: dgramos_vet@hotmail.com; marys_torres@hotmail.com; isisab@gmail.com

2 Discente de Mestrado, UFMT, Cuiabá, MT, Brasil. E-mail: brunazocco@hotmail.com

3 Profs. Adjuntos, UFMT, Cuiabá, MT, Brasil. E-mail: richard@ufmt.br; alsinkoc@ufmt.br

* Author for correspondence
} 
Helminths may be responsible for respiratory and gastrointestinal infections, weight loss, developmental delay, progressing to cachexia and death, especially in neonates and young animal's age group that is more commonly affected (HOFFMANN et al., 1990).

Larva migrans syndromes, especially toxocariasis and hookworm infections are among the most prevalent zoonosis in the world, however these diseases are still unknown by the population (WELLS, 2007). These parasitic zoonosis are associated with the presence of dogs and cats in public places such as parks and squares (RUBINSKYELEFANT et al., 2010)

Non domiciled dogs are epidemiologically important in environmental contamination, as weel as animals that not receive antiparasitic treatment routinely, and roads in public areas (PALMER et al., 2007). In Brazil has been reported contamination of soil in urban areas up to $60.3 \%$, including areas reserved for human recreation (TIYO et al., 2008; RUBINSKY-ELEFANT et al., 2010). In European countries the soil contamination may reach around $87.1 \%$ as (RUBINSKY-ELEFANT et al., 2010).

Cuiabá has an estimated population of 50,143 dogs (CUIABÁ, 2010), of which 70\% has access to public areas, thus the objective of this study was to collect, identify and calculate the mean intensity of parasitism (MIP) and mean abundance population (MAP) of the helminthes species found in dogs from Cuiabá, Mato Grosso State, Midwestern of Brazil.

During March 2007 to August 2008, 100 freeranging dogs (Canis lupus familiaris) captured by the Zoonosis Control Centre of Cuiabá municipality (CCZ/Cuiabá) were necropsied. These animals were caught in public areas and euthanized according to the protocol of the American Veterinary Medical Association (AVMA), Guidelines on Euthanasia (AVMA, 2001) by CCZ/Cuiabá. This study was approved by the Ethics Committee on Animal Research of the Federal University of Mato Grosso (Protocol N.. 23108.027980/10-8).
During the necropsy, the esophagus, stomach, small intestine and large intestine were individually washed and filtered in $0.15 \mathrm{~mm}$ sieve, and examined in stereomicroscope under 10x magnification. The same procedure was used for the liver (gallbladder and bile ducts), pancreas, heart, kidneys, bladder and ureters. The lungs were opened by the bronchial tree for washing the content in the sieve, and later searched for parasites and/or injuries and, in these situations, fragments were subjected to histopathological examination stained by hematoxylin-eosin (UENO; GONÇALVES, 1998).

All parasitic worm found were collected and processed according to Hoffmann (1987). The identification was carried out following specific keys according to each taxonomic group: Anderson, Chabaud and Wilmott (2009), for nematodes, and Khalil, Jones and Bray (1994) for cestodes.

Prevalence, MIP and MAP were calculated according to Bush et al. (1997), using the software Quantitative Parasitology 3.0. Prevalence statistical analysis were performed using the methodology of generalized linear models (GLM) using a binomial distribution (presence or absence of the characteristic), with the aid of the logistic link function as a linear predictor.

On the whole 8,217 helminths was founded in 85 animals $(85 \%)$, with 6 species identified as: Ancylostoma caninum (Ercolani, 1859), Ancylostoma braziliense (Faria, 1910), Trichuris vulpis (Froelich, 1789), Toxocara canis (Werner, 1782), Dirofilaria immitis (Leidy, 1856) and Dipylidium caninum (Linnaeus, 1758).

Ancylostoma caninum was the most prevalent specie $(76 \%-\mathrm{p}<0.05)$, with higher mean intensity (87.34), and mean abundance (66.38). Although $A$. braziliense has shown high MIP, its prevalence and abundance were lower than $A$. caninum. Moreover, $D$. immitis showed the lowest values found for all variables. Prevalence, MIP and MAP for other helminths species are presented in Table 1. The most 
absolute abundant specie was A.caninum followed significant difference between the other species ( $p$ by T. vulpis (Figure 1). There was no statistically $<0.01$ ).

Table 1. Prevalence, mean intensity, mean abundance and range of helminths species of 100 dogs in Cuiabá, MT, Brazil, from 2007-2008.

\begin{tabular}{|c|c|c|c|c|c|c|}
\hline \multirow{2}{*}{ Species } & \multicolumn{3}{|c|}{ Prevalence \% $(p<0.05)$} & \multirow{2}{*}{$\begin{array}{c}\text { Mean } \\
\text { Intensity }\end{array}$} & \multirow{2}{*}{$\begin{array}{c}\text { Mean } \\
\text { Abundance }\end{array}$} & \multirow{2}{*}{ Range } \\
\hline & Lower & Mean & Upper & & & \\
\hline \multicolumn{7}{|l|}{ Nematodes } \\
\hline Ancylostoma caninum & 74.1 & 76 & 76.9 & 87.34 & 66.38 & $1-784$ \\
\hline Ancylostoma braziliense & 1.95 & 2 & 2.05 & 109.5 & 2.19 & $15-204$ \\
\hline Trichuris vulpis & 41.92 & 43 & 44.07 & 23.33 & 10.03 & $1-181$ \\
\hline Toxocara canis & 17.55 & 18 & 18.45 & 14.94 & 2.69 & $1-82$ \\
\hline Dirofilaria immitis & 0.97 & 1 & 1.02 & 6 & 0.06 & 6 \\
\hline \multicolumn{7}{|l|}{ Cestodes } \\
\hline Dipylidium caninum & 31.2 & 32 & 32.8 & 2.56 & 0.82 & $1-7$ \\
\hline
\end{tabular}

Source: Elaboration of the authors.

Ramos et al. (2013) investigated the helminth parasites of stray cats in metropolitan area of Cuiabá showed a prevalence of $60.96 \%$ for Ancylostoma spp., being the most prevalent and abundant species in cats, close to those observed in this study. Cutaneous larva migrans has been described as a public health problem in Cuiabá, and usually occurs by the negligence, and lack of knowledge of the population about this zoonotic disease, caused especially by the genus Ancylostoma, which has a high biotic potential, especially in months with more rainfall, and increases of environmental contamination (ALMEIDA; CÂNDIDO; SOUSA, 2010). Beyond, accidental sporadic cases of $A$. caninum has been described in humans (BOWMAN, 2009).

The prevalence $(50.68 \%)$ described by Ramos et al. (2013) to $A$. braziliense in cats, demonstrated wide distribution and abundance of that species in the same region of this study. Despite $A$. braziliense mature in dogs and cats (BOWMAN, 2009), the low prevalence $(1.95 \%)$ observed in dogs, showed the parasitic specificity of the helminthic species and their hosts. Beyond, A. caninum is much more pathogenic for dogs than A. braziliense, because it causes much greater blood loss per worm (BOWMAN, 2009).

Trichuris vulpis has been commonly reported in dogs, causing bloody diarrhea, mainly due to their intense tissue penetration (BOWMAN, 2009). $T$. canis and D. caninum are zoonotic diseases and have also been described in cats in the region of Cuiabá (RAMOS et al., 2013). D. caninum is described mainly affecting children, who may ingest accidentally the intermediate host (fleas or lice). While T. canis is the agent responsible for visceral and ocular larva migrans (RUBINSKYELEFANT et al., 2010), and has been described being responsible for eosinophilic pneumonia in humans (DEMIRCI et al., 2012).

Dirofilaria immitis is a zoonotic parasitic disease mainly located in temperate, tropical, and subtropical areas of the world, using different species of culicid mosquitoes (Culex spp., Aedes spp., Anopheles spp.) as an intermediate host (BOWMAN, 2009). Despite its occurrence in just one dog (1\%), Fernandes et al. (2000) described a seroprevalence of $11.81 \%$ 
of D. immitis in dogs from Cuiabá using indirect parasite, only antibodies anti- D. immitis (SILVA; methods, so being not effective in detecting the LANGONI, 2009).

Figure 1. Absolute abundance of helminths species of 100 dogs in Cuiabá, MT, Brazil, from 2007-2008. Source: Elaboration of the authors.

7000

6000

5000

4000

3000

2000
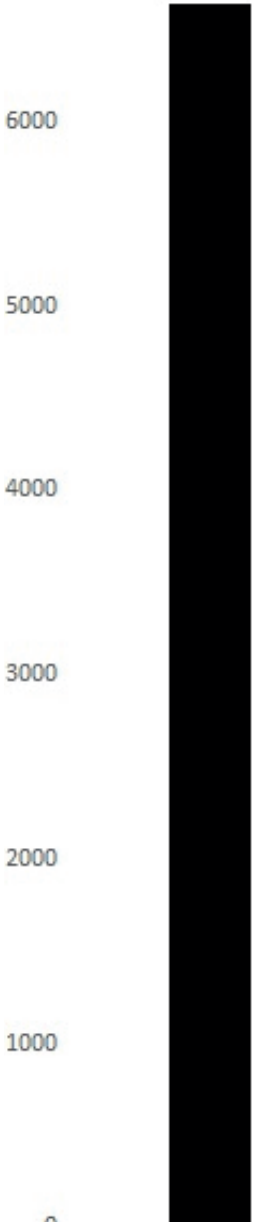

0

Ancylostoma caninum

Trichuris vulpis

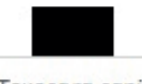

Ancylostoma braziliense Dipylidium caninum

Dirofilaria immitis

It was evidenced the wide distribution of References

helminths pathogenic to domestic dogs, and especially with zoonotic potential as A. caninum, $T$. canis, D. caninum and D. immitis. However, further research is required to feature the real importance of $D$. immitis as a cause of heart disease in domestic dogs in the region.

The authors are grateful to the Zoonosis Control Centers of Cuiabá, for providing the samples.
ALMEIDA, A. B. P. F.; CÂNDIDO, A. C.; SOUSA, V. R. F. Larvas de helmintos em áreas de recreação de creches de Cuiabá, Mato Grosso. Semina: Ciências Agrárias, Londrina, v. 31, n. 2, p. 469-472, 2010.

AMERICAN VETERINARY MEDICAL ASSOCIATION - AVMA. 2000 Report of the AVMA panel on Euthanasia. Journal of the American Veterinary Medical Association, Schaumburg, v. 218, n. 5, p. 669696, 2001. 
ANDERSON, R. C.; CHABAUD, A. G.; WILMOTT, S. Keys to the nematode parasites of vertebrates: archival volumes. Cambridge: Cabi, 2009. 463 p.

BOWMAN, D. D. Georgis' parasitology for veterinarians. $9^{\text {th }}$ ed. St. Louis: Saunders Elsevier, 2009. $432 \mathrm{p}$.

BUSH, A. O.; LAFFERTY, K. D.; LOTZ, J. M.; SHOSTAK, A. W. Parasitology meets ecology on its own terms: Margolis et al. revisited. Journal of Parasitology, Laurence, v. 83, n. 4, p. 575-583, 1997.

CUIABÁ. Secretaria Municipal de Saúde. Campanha de vacinação anti-rábica atinge meta em 2010. Prefeitura de Cuiabá, 2010. Disponível em: <http://www.cuiaba. mt.gov.br/noticias?id=226>. Acesso em: 12 jul. 2011.

DEMIRCI, M.; UNLU, M.; FIDAN, F.; KAYA, S. Eosinophilic pneumonia due to toxocariasis: an adult case report. Turkiye Parazitolojii Dergisi, Istambul, v. 36, n. 4, p. 258-259, 2012.

FERNANDES, C. G. N.; RODRIGUES-SILVA, R.; MOURA, S. T.; OLIVEIRA, R. M. F. Aspectos epidemiológicos da dirofilariose canina no perímetro urbano de Cuiabá, Mato Grosso: emprego do "Immunoblot" e do teste de Knott modificado. Brazilian Journal of Veterinary Research and Animal Science, São Paulo, v. 37, n. 6, 2000. Disponível em: <http://dx.doi. org/10.1590/S1413-95962000000600009>. Acesso em: 23 nov. 2010.

HOFFMANN, R. P. Diagnóstico de parasitismo veterinário. Porto Alegre: Sulina, 1987. 156 p.

HOFFMANN, R. P.; FORTES, E.; PANDOLFO, R. A.; KAISER, J. C.; BELLO, A. R. R.; MOTTA-NETO, A. A. Prevalência de helmintos gastrointestinais do cão errante do município de Porto Alegre, Rio Grande do Sul. Arquivo da Faculdade de Veterinária da UFRGS, Porto Alegre, v. 18, n. 1, p. 61-68, 1990.
KHALIL, L. F.; JONES, A.; BRAY, R. A. Keys to the cestode parasites of vertebrates. Cambridge: Cabi, 1994. $751 \mathrm{p}$.

PALMER, C. S.; TRAUB, R. J.; ROBERTSON, I. D.; HOBBS, R. P.; ELLIOT, A.; WHILE, L.; REES, R.; THOMPSON, R. C. A. The veterinary and public health significance of hookworm in dogs and cats in Australia and the status of A. ceylanicum. Veterinary Parasitology, Amsterdam, v. 145, n. 3-4, p. 304-313, 2007.

RAMOS, D. G. S.; SCHEREMETA, R. G. A. C.; OLIVEIRA, A. C. S.; SINKOC, A. L.; PACHECO, R. C. Survey of helminth parasites of cats from the metropolitan area of Cuiabá, Mato Grosso, Brazil. Revista Brasileira de Parasitologia Veterinária, São Carlos, v. 22, n. 2, p. 201-206, 2013.

RUBINSKY-ELEFANT, G.; HIRATA, C. E.; YAMAMOTO, J. H.; FERREIRA, M. U. Human toxocariasis: diagnosis, worldwide seroprevalences and clinical expression of the systemic and ocular forms. Annals of Tropical Medicine and Parasitology, Liverpool, v. 104, n. 1, p. 3-23, 2010.

SILVA, R. C.; LANGONI, H. Dirofilariose. Zoonose emergente negligenciada. Ciência Rural, Santa Maria, v. 39, n. 5, p. 1614-1623, 2009.

TIYO, R.; GUEDES, T. A.; FALAVIGNA, D. L.; FALAVIGNA-GUILHERME, A. L. Seasonal contamination of public squares and lawns by parasites with zoonotic potential in southern Brazil. Journal of Helminthology, Egham, v. 82, n. 1, p. 1-6, 2008.

UENO, H.; GONÇALVES, P. C. Manual para diagnóstico das helmintoses de ruminantes. $4^{\text {th }}$ ed. Tokyo: Japan International Cooperation Agency, 1998. p. 80-82.

WELLS, D. L. Public understanding of toxocariasis. Public Health, Edinburgh, v. 121, n. 3, p. 187-188, 2007. 
